\title{
Dosimetrie von Röntgen- und Gammastrahlen mittels photographischer Filme
}

\section{Doctoral Thesis}

Author(s):

Mauderli, Walter

Publication date:

1957

Permanent link:

https://doi.org/10.3929/ethz-a-000104577

Rights / license:

In Copyright - Non-Commercial Use Permitted 


\title{
Dosimetrie \\ von Röntgen- und Gammastrahlen \\ mittels photographischer Filme
}

\author{
VON DER \\ EIDGENÖSSISCHEN TECHNISCHEN \\ HOCHSCHULE IN ZÜ R ICH \\ ZUR ER LAN GUNG \\ DER WÜRDE EINES DOKTORS DER \\ NATURWISSENSCHAFTEN \\ GENEIMIGTE \\ PROMOTIONSARBEIT \\ VORGELEGT VON \\ WALTER MAUDERLI \\ von Basel \\ Ser

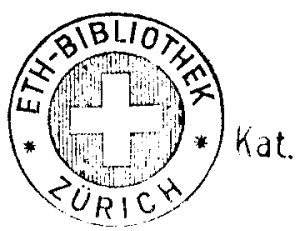

Referent: Herr Prof. Dr. P. Scherrer

Korreferent: Herr Prof. Dr. J. Eggert

1957

GEORG THIEMEVERLAG - STUTTGART 
Anmerkung

Bei sämtlichen Versuchen wurde jeweils der Gevaert-Entwickler G 230 angewendet.

Entwicklungszeiten : 5 min bei einer Temperatur zwischen 19,5 und $20,5^{\circ} \mathrm{C}$.

Filme, deren Schwärzungen miteinander in Beziehung gesetzt wurden, sind stets gleichzeitig entwickelt worden.

\section{Zusammenfassung}

Der Schwärzungseffekt bei Einwirkung von Röntgenstrahlen auf photographische Filme wurde in Beziehung gesetzt mit der in AgBr absorbierten Energie. Es wurde gezeigt, daß die Schwärzung nicht nur von der absorbierten Energie, sondern außerdem noch ganz wesentlich von der mittleren Ionendichte abhängt. Es wird hingewiesen auf den Einfluß des Gelatine-Gehalts und der Korngröße nach dem Entwickeln. Es werden extrem verdünnte AgBr-Schichten untersucht im Hinblick auf eine Verkleinerung der Wellenlängenabhängigkeit. Wegen des Einflusses der Ionendichte kann diese jedoch nicht im gewünschten Maß vermindert werden. Dann werden die verschiedenen Filtermethoden und die Fehlerquellen in der Dosisbestimmung betrachtet. Eine Apparatur für die Ausmessung der Personalfilme wird beschrieben.

\section{Summary}

The effect of X-rays on emulsions of photographic films is related to the energy absorbed in silver-bromide. It is pointed out that photographic density does not only depend on absorbed energy but also significantly on the mean ionization density. The influence of the gelatine-content and the grain-size (after development) are emphasized. Extremely diluted silver-bromide emulsions were tested with the object of reducing wavelengthdependence. Due to the influence of ion-density, however, wavelength-dependence cannot be reduced in any desirable way. Furthermore the different filter-methods and the sources of error in the determination of the dose have been analysed. An apparatus for evaluating monitoring films is described.

\section{Résumé}

L'effet du noircissement résultant de l'action des rayons X sur le film photographique est mis en rapport avec l'énergie absorbée par le bromure d'argent. L'auteur montre que le noircissement ne dépend pas seulement de l'énergie absorbée, mais encore et de façon importante de la densité moyenne des ions. Il nous rend en outre attentif à l'influence de la teneur en gélatine et aux dimensions des grains après le développement. Des couches extrêmement diluées de bromure d'argent ont été examinées pour rechercher une diminution de l'influence de la longueur d'onde. Cette dernière ne peut être toutefois réduite dans la mesure souhaitée en raison de l'influence de la densité des ions. Les différentes méthodes de filtrage et les causes d'erreurs dans la détermination des doses sont ensuite étudiées. Description d'un appareil permettant de mesurer les films du personnel.

$(A .-M . M$.

\section{Resumen}

Se relacionó el efecto de ennegrecimiento por la incidencia de rayos Roentgen sobre films fotográficos con la energía absorbida por el bromuro de plata. Se demuestra que el ennegrecimiento depende no solamente de la energía absorbida sino también, y en fundamental medida, de la densidad iónica media. Se señala la influencia del contenido en gelatina y del tamaño del grano después de la revelación. Se examinan capas de bromuro de plata extrenadamente diluídas en relación a una reducción de la dependencia de la longitud de onda. Como consecuencia de la densidad iónica esta no puede ser reducida en forma deseable. Por otra parte se tienen en cuenta los distintos métodos de filtraje y los factores de error en la determinación de la dosis. Se describe un dispositivo instrumental para valoración de los films.

\section{Schrifttum}

(1) Kienböck, R.: Radiotherapie. Ferdinand Enke Verlag, Stuttgart 1907. - (2) Breitling, G.: Ubber die Wellenlängenabhängigkeit der Fluoreszenz organischer Leuchtstoffe im Röntgengebiet. Z. angew. Physik 4 [1952]. - (3) Laughlin, J. S., Beattie, J. W., Ovadia, J.: Calorimetric determination of the roentgen for $400 \mathrm{kV}$ X-rays. Phys. Rev. 85 [1952]. — (4) Laughlin, J. S., Beattie, J. W.: Calorimetric determination of the energy flux of 22,5 MeV X.rays. Rev. Sc. Instrum. 22 [1951]. - (5) Dresel, H.: Filmdosimetrie bei Strahlenschutzmessungen. Fortschr. Röntgenstr. 84 [1956]. - - (6) Spiegler, G.: Photographic protection measurements with X-rays, gamma and beta rays. Phot. J. 91 B [1951]. - (7) White, G. R.: X-ray attenuation coefficients from $10 \mathrm{keV}$ to $100 \mathrm{MeV}$, Report 1003. National bureau of standards, U.S. department of commerce, Washington, D. C. 1952. - (8) May neord, W. V.: Some application of nuclear physics to medicine. Brit. J. Radiol. 2 [1950].(9) Burhop, E. H. S.: The auger effect and other radiationless transitions. - (10) Fine, S., Hendee, C. F.: X-ray critical absorption and emission energies in keV. Nucleonics 3 [1955]. — (11) Sieg ba h n, M.: Spektroskopie der Röntgenstrahlen. Julius Springer, Berlin 1931. - (12) Bergström, I., Wils on, R., Wu, C. S.: Some internal effects in nuclear decay. Beta and gamma ray spectroscopy by K. Siegbahn. - (13) Gray, L. H. : An ionization method for the absolute measurement of gamma ray energy. Proc. Roy. Soc. 156 A [1936]. - (14) Paul, W., Ste in we del, H.: Interaction of electrons with matter. Beta and gamma ray spectroscopy by $\mathbf{K}$. Siegbahn. - 